\title{
Exchange agreement
}

In spite of new agreements, there is scope for more scientific visits between the UK and USSR. Vera Rich reports

A NEW agreement on the exchange of scientific visits was signed in Moscow last month by Lord Todd on behalf of the Royal Society and Academician Anatolii A. Aleksandrov for the Soviet Academy of Sciences. Although the negotiations took place in what Aleksandrov described as a "friendly and constructive" atmosphere, and although Lord Todd told Nature that he felt that "good progress had been made", the details of the latest agreements reveal just how much progress in scientific exchange still remains to be made.

The new agreement provides for a two-way traffic of seven senior and four junior visits per year. Senior scientists will visit the host country for 3-6 weeks and junior scientists for $8-10$ months at a time, the total yearly quota being 40 man-months. This seems negligible compared with the 50 . 100 short-term visits per year between the UK and the major EEC countries or with UK-Poland exchanges, where there is an annual flow of some 80 visits to Britain and 40 visits to Poland. Leaving aside the special case of the English-speaking countries, one would expect the flow of exchange visits to be roughly proportional to the size and scientific importance of the country concerned. The anomalous position of Soviet-UK exchanges is apparently recognised by both parties; according to Lord Todd, both sides agreed that in so far as finances permit, they would like to see the number of exchanges increased, especially among junior scientists.

There is no great enthusiasm in the UK, however, to take up even the number of exchange places available. One reason is obviously language; most Soviet scientists have at least a reading knowledge of English, but the need for a reciprocal knowledge of Russian has largely been obviated in recent years by the expansion of cover-to-cover journal translation programmes. It is also extremely difficult for young British scientists to discover how they would benefit from an exchange visit.

The Royal Society delegation pressed for more explicit information on the work being done at the various Soviet Institutes. They were assured that intending visitors could find all they needed to know from journals such as Priroda (Nature) and Nauka i Zhizn' (Science and Life). These semi-popular journals are, in fact, designed to give a general idea of current progress rather than to specify the work of individual scientists or institutes; moreover, they are in Russian (the translation programmes deal with specialist journals only), as is the more informative Vestnik (Bulletin) of the Academy of Sciences.

The new agreement does, however, include one rather promising provision-the extension of joint research projects. Working visits between the teams involved would not necessarily come out of the 40 man-months of the basic programme.

\section{Rock energy}

David Davies reports from Washington on the US programme to exploit geothermal energy

WITH the United States importing nearly half of its petroleum now, it is no wonder that even modest contributions to the nation's energy budget assume a growing importance. The geothermal energy programme in the US Department of Energy (DOE) could only displace a few per cent. of the nation's fossil fuel requirements by the year 2000 but is authorised this financial year to spend $\$ 116$ million, double last year's authorisation and nearly five times the figure of four years ago.

Resources are divided into three categories of increasing magnitude but also of increasing difficulty of exploitation. Convective hydrothermal resources comprise both dry-steam systems, of which the Geysers field in California (extracting $500 \mathrm{MWe}$ at present but eventually 2,000 MWe) is probably the only US example, and liquid-dominated reservoirs, of which there are many at temperatures upward of $90^{\circ} \mathrm{C}$. Geopressured resources consist of methane dissolved in water at moderate temperatures. The water is in isolated reservoirs at the pressure of the overlying rock, much greater than the hydrothermal pressure, and heat, methane and hydraulic power can all be extracted. The resource is concentrated around the Gulf states. Finally there are 'hot dry rocks', rocks at relatively high temperatures near the surface into which water must be introduced to extract the heat.

Dry steam already provides $5 \%$ of California's electrical needs at a very attractive price and has needed little government support. Liquid-dominated reservoirs, on the other hand, have needed a stimulus; DOE has just issued a request for bids to build a $50 \mathrm{MWe}$ demonstration plant in the western United States that will be economic and socially and environmentally acceptable. The department hopes to sign a contract for this in mid-1978. But the real and growing optimism, according to Dr James Bresee, director of the programme, is in the potential of the hydrothermal resource for direct-heat applications.

Geopressured resources have a much larger question mark against them. There are major unanswered issues of reservoir producibility and longevity, and so far there has been little com- mercial interest. Nevertheless, DOE plans to go ahead this year with welltests in Texas and Louisiana, and has proposed pilot plants for energy recovery.

The hot-dry-rock experiment at Los Alamos, although it has attracted the widest attention, must at present be regarded as the most speculative of all. A fractured zone has been created at a depth of $3 \mathrm{~km}$ in granite, and water is run down one pipe, through the granite, and up through a second. The rising hot water flashes to steam. Less than $10 \%$ of the water is lost underground. So far the heat extracted (about $3 \mathrm{MWt}$ ) is less than had been expected, so the next few months will be a crucial time for this programme.

Not all the obstacles to geothermal energy are technical. DOE employs about six professionals simply to look at the so-called institutional barrierstax laws, environmental regulations and so on. At last count at least six governmental departments and over ten major agencies are involved in some way or another. Further, although the federal government has established loan guaranties for up to $75 \%$ of any loans to the geothermal industry, the widely-expected flood of applicants has not materialised; so far only two guaranties have been made, apparently because large companies would rather act as their own guarantor. 